\title{
Semnificația ca reflex al contactelor lingvistice
}

\author{
Enikő Pál* \\ Facultatea de Științe Economice și Umaniste, Universitatea Sapientia, Piața Libertății 1, 530104 Miercurea Ciuc, România
}

\section{Despre articol}

Istoric:

Primit 30 mai 2014

Acceptat 29 iunie 2014

Publicat 13 ianuarie 2015

Cuvinte-cheie:

contact lingvistic

împrumut lexical

vechea română literară

\begin{abstract}
Rezumat
Studiul de faţă se înscrie pe direcția actualizării în lingvistica românească a teoriilor privitoare la interferențele lingvistice (româno-maghiare) manifestate în unele comunități bilingve și a cercetării particularităţilor lexicale pătrunse în limba română scrisă prin influența graiurilor maghiare vorbite în diferite zone ale țării sau chiar prin traducerea în română a unor texte maghiare. Preocuparea de bază o constituie împrumuturile maghiare lexicale vechi din limba română care sînt discutate din perspectiva schimbărilor petrecute în planul semnificației. Inventarierea sensurilor împrumuturilor maghiare s-a efectuat pe baza unui corpus de texte românești vechi, ținîndu-se cont și de materialul oferit de diverse dicționare cu preocupări (și) etimologice. Așa cum reiese din cele cîteva exemple analizate în cadrul prezentului studiu, sensul lexical este impregnat atît de intelect, cît și de afectivitate. Însă universul emoțional este rareori preluat o dată cu termenul împrumutat. Cel mai des, conținutul afectiv este, la rîndul lui, adaptat conform sensibilității și spiritualității proprii vorbitorilor care împrumută.
\end{abstract}

Motto: „Dacă te uiți atent la bobul de grîu vezi în el chipul lui Iisus”, spune o vorbă din bătrîni (Izvorul. Revistă de etnografie și folclor, nr. 30, Giula, 2009, p. 22). La fel cum moartea și viața spirituală se găsesc încapsulate în simplitatea unui bob de grîu, într-un singur cuvînt se așterne un univers întreg de gîndiri și de simțiri.

\section{Psihologia și istoria limbii. Preliminarii}

Ideea conform căreia limba, psihicul uman și spiritul național reprezintă entități indisolubil contopite, are o vechime considerabilă în științele limbajului, fiind formulată, în mod explicit, de către W. von Humboldt. Astfel, „doar în individ, limba își dobîndește determinarea ultimă” (Humboldt, 1836/2008, p. 99), pe de o parte, și ,în orice limbă este implicată o viziune specifică asupra lumii”, cu alte cuvinte, „orice limbă conține întreaga țesătură de concepte și modul de reprezentare ale unei părți a umanității” (ibidem, p. 95), pe de altă parte. Iar, dacă în limbă se răsfrînge ceea ce gîndește și simte un popor, atunci varietatea limbilor reflectă, în esență, o diversitate spirituală. Aceste idei, inovatoare în contextul epocii lingvistului german, astăzi devenite aproape locuri comune, au pornit o adevărată avalanșă a cercetărilor psiholingvistice, îndeosebi începînd cu cea de-a doua jumătate a secolului al XIX-lea.

Această schimbare de paradigmă în științele limbajului se petrece relativ concomitent cu fondarea unei ramuri noi în domeniul psihologiei. Premisa acesteia consta în observația că spiritul unei colectivităţi (cu repercusiuni și asupra limbajului) trebuie socotit ca fiind diferit de spiritul individual, prin urmare, trebuie să se admită și existența unei etnopsihologii (Völkerpsychologie), alături de psihologia individuală. Noua disciplină și-a propus studiul acelor principii și procese psihologice care stau la baza și care guvernează relațiile sociale, respectiv evoluția vieții socioumane, pe de o parte, și nașterea și evoluția produselor spirituale comune ale unei colectivități, rezultate în urma interacțiunii sociale, pe de altă parte. Printre acestea din urmă se numără și limba. Însă, spre deosebire de perspectiva istorică, din care o anumită formă lingvistică, spre exemplu un împrumut, poate interesa cercetătorul prin faptul că aceasta păstrează amintirea relaţiei de

*Adresă de corespondență: enikopaldr@gmail.com. 
altădată dintre două comunități umane, din perspectivă etnopsihologică, aceasta interesează doar atunci cînd în forma respectivă se manifestă principii general umane ale evoluției limbii.

Primele încercări de a oferi explicații psihologice pentru fapte de istorie a limbii se găsesc la Steinthal $(1855,1865)$. Opera acestuia poate fi privită ca programul unei direcții noi, în care psihologia ia locul filosofiei limbajului pentru prima dată. În aceeași direcție se înscrie și Paul (1886), continuatorul acestuia, în opinia căruia explicațiile fenomenelor lingvistice trebuie căutate în interacțiunea spirituală a omului cu mediul înconjurător. În elaborarea sistemului său, autorul întrebuințează rezultatele oferite de psihologie pentru scopuri lingvistice. O perspectivă oarecum diferită se găsește la Wundt (1904). Astfel, pe el nu atît faptele lingvistice îl interesează, cît procesele și principiile psihologice care rezultă din ele. Cu alte cuvinte, pentru el istoria limbii reprezintă un material bogat care poate fi valorificat în explicarea diverselor fenomene psihologice.

Fie că se pornește de la mecanisme psihologice pentru explicarea fenomenelor lingvistice, fie că se urmărește un demers invers, interdependența limbă - gîndire - societate rămîne indiscutabilă. În mod evident, limba reflectă universul reprezentărilor, al asocierilor mentale caracteristice unei colectivități, astfel încît bogăția vocabularului unei limbi corespunde, în linii mari, bogăției lumii reprezentărilor mentale de care dispune colectivitatea care o vorbește. Tot așa, formarea cuvintelor și relațiile morfosintactice ale acestora într-o limbă lasă să se întrevadă principiile și formele asocierilor mentale posibile și exersate în cadrul comunităţii. În acest sens, în schimbările semantice ale cuvintelor se manifestă, în fapt, principiul schimbării reprezentărilor.

Privind limba ca supremul instrument al conștiinței unei colectivități, abordarea istorică, respectiv cea psihologică a limbii, cu toate că urmăresc finalități deosebite, nu pot fi privite ca două entităţi net separabile, ci ca două perspective care se sprijină una pe cealalta și care se completează. Astfel, cu toate că lingvistica diacronică este interesată de limbă, în primul rînd, ca de un fenomen istoric, și mai puțin ca de o problemă psihologică, studiul psiholingvistic al limbii poate fi extrem de fructuos pentru cercetările de istorie a limbii (cf. și Gombocz, 1898).

\section{Latura psihologică a cuvîntului}

Din punct de vedere psihologic, cuvîntul reprezintă o îmbinare a unor reprezentări mentale diferite, o „complicație” a acestora, adică conexiunea simultană a unor reprezentări disparate (cf. Wundt, 1893, p. 209; Gombocz, 1997, p. 134). Astfel, complexul sonor (semnificantul) presupune o îmbinare a două tipuri de reprezentări: a imaginii acustice (= reprezentarea senzorială a sunetului, adică receptarea acestuia: auzim ce se spune și ce spunem noi) și a unei imagini dinamice (= reprezentarea senzaţiei de mișcare, adică articularea sunetului: simțim funcționarea organelor noastre fonatoare, a mușchilor etc.). Cealaltă componentă a „complicației” cuvîntului o constituie imaginea conceptuală (semnificatul), acel conținut al reprezentării pe care vorbitorul și ascultătorul îl asociază cu numele. În cazul oamenilor alfabetizați, la acestea se mai adaugă și imaginea grafică a cuvîntului care îmbină reprezentările literelor care compun lanțul sonor și reprezentările mișcărilor de scriere. Altfel spus, un cuvînt implică două imagini senzoriale (auditive și vizuale) și două imagini motrice (orale și manuale) (cf. Vendryes, 1921, p. 79).

Între imaginea lanțului sonor și cea conceptuală există o strînsă legătură asociativă. Lucrul acesta explică puterea evocatoare a semnificantului. În cadrul unei comunități, unui cuvînt rostit i se asociază acelaşi sau aproape acelaşi conținut noțional la vorbitor, ca și la ascultător. Înţelegerea între vorbitor și ascultător cunoaște grade diferite, în funcție de măsura în care acest conținut este identic sau apropiat la cei doi interlocutori.

Însă un cuvînt dispune nu doar de o putere evocatoare, ci și de o forţă inductoare de dispoziții, de stări sufletești. Atfel spus, sensul asociat unui complex fonetic nu se compune doar din reprezentări noționale, ci și din elemente emoționale (cf. szóhangulat la Zolnai, 1920; érzelmi velejáró la Simonyi, 1916; Gefühlston, Gefühlswert der Worte la Wundt, 1904; valeur affective la Bally, 1926; emotional elements in words). Valoare afectivă poate avea atît conținutul reprezentării, cît și lanțul sonor, iar aceasta, la rîndul 
ei, este rezultatul unei evoluții istorice, ca și semnificatul sau semnificantul. Influențat de conținut sau independent de acesta, complexul sunetelor articulate poate produce o anumită stare de spirit, asemenea sunetelor muzicale. Acest efect estetic se realizează, de regulă, prin sonoritatea cuvintului, adică prin alternanța, distribuția și ordinea sunetelor sonore și surde. Alături de calitatea sunetelor ${ }^{1}$, o senzație plăcută sau neplăcută poate produce și accentul, intonația sau ritmul vorbirii, în funcție de care diferite cuvinte sînt percepute ca fiind plăcute sau neplăcute, frumoase sau urîte. Spre exemplu, mgh. szello" 'adiere, briză' este perceput ca fiind plăcut, frumos, armonios, din punct de vedere acustic, pe cînd mgh. kecsegtet 'amăgește, promite' este neplăcut auzului, urît. $\mathrm{O}$ altă situație interesantă o reprezintă asocierea unor valori afective diferite fiecărui lexem dintr-o pereche sinonimică. De pildă, în maghiară cuvintele apa 'tată, părinte' și atya 'părinte, tată, deși desemnează același conținut, funcționînd, din punct de vedere logic, ca sinonime, au valori afective diferite, trezind emoții deosebite (cf. Gombocz, 1997, p. 102, 139). Această diferență este semnalată și în dicționarul elaborat de Czuczor \& Fogarasi, unde se face următoarea observație: „în ceea ce privește uzul, distincția între apa și atya pare a consta în faptul că apa se întrebuințează în limbajul cotidian, se bucură de o mai mare popularitate și sugerează familiaritate, pe cînd atya este mai manierat, sugerînd respect, cu acesta fiind desemnate, în special, persoane de un anumit rang sau de o anumită funcție (înaltă, s.n.)" (s.v. atya). Natura conținutului emoțional asociat fiecăruia în parte determină și contextele lor de întrebuințare. Astfel, apa se întrebuințează cînd se urmărește indicarea naturii intime, confidențiale și afectuoase a unei relații (cf. édesapám 'dulce tată', Kossuth apánk 'tatăl nostru Kossuth'), cînd se desemnează relația tată - copil, fără nici o tonalitate afectivă (cf. az apjára ütött 'seamănă cu tată-său') sau în expresii mai dure și jignitoare, în imprecațiile din limba comună populară (cf. az apád istenit!). Spre deosebire de acesta, atya se întrebuințează atunci cînd sentimentul dominant este de respect, în contexte de solemnitate (cf. uram atyám 'Doamne, Dumnezeule', Miatyánk 'Tatăl nostru (rugăciune)', lelki atya 'părinte spiritual (duhovnic)', a haza atyja 'părintele patriei').

În mod evident, situația împrumuturilor se prezintă cu totul specială. Acestea poartă în sine asocierile conceptuale și emoţionale caracteristice comunității donatoare care se reflectă în limba-sursă, adică în etimon, însă continuă o viață particulară în limba-țintă, fiind adaptate la universul conceptual și afectiv al comunității primitoare. Astfel, este de înțeles că nu numai reprezentările noționale (sensul împrumuturilor) suferă schimbări, ci și atitudinile manifestate faţă de lumea obiectuală pe care o reflectă, fie că erau cunoscute anterior în comunitatea-țintă, fie că nu, și, în același timp, lanțul fonetic însuși capătă valențe emoțional-expresive noi, pe de o parte, deoarece sunetele limbii-țintă cunosc alte particularităţi fonetice (alte trăsături articulatorii, altă distribuție etc.) față de sunetele cvasi-corespunzătoare ale etimonului și, pe de altă parte, deoarece, adesea, împrumutul se prezintă în limba de ieşire ca un lexem neanalizabil, nemaipermiținnd segmentarea componențială, care era posibilă în cazul etimonului ${ }^{2}$.

\section{Psihologia schimbărilor semantice}

Schimbarea sensului unui cuvint este, în esență, un proces psihologic. Atunci cînd se explică modificările petrecute în planul semnificației unui cuvînt, în mod inevitabil, trebuie să luăm în considerare şi factori extralingvistici, precum: atributele, reale sau percepute ca find reale, ale obiectului desemnat, funcția pe

\footnotetext{
${ }^{1}$ Natura sunetelor poate fi purtătoare nu numai de expresivitate, ci și de conținut noțional. În limbile finougrice, condiționat și de armonia vocalică, perechii vocalice palatal - velar i se asociază și un conținut conceptual diferit sau, în orice caz, de nuanță deosebită. Astfel, de pildă, în cazul pronumelui demonstrativ, variantei velare i se asociază reprezentarea mentală, noțiunea 'distanță mai mare', pe cînd celei palatale înțelesul 'distanță mai mică' (vezi mgh. $\boldsymbol{e} z$ 'acesta' - $\boldsymbol{a} z$ 'acela', itt 'aici' - ott 'acolo', ide 'încoace' - oda 'într-acolo', ilyen 'astfel de' - olyan 'așa fel de', így 'în felul acesta (așa)' - úgy 'în felul acela' etc.). Tot așa, în cadrul verbelor sau al numelor, variantele palatale și velare din perechile de cuvinte sinonimice se disociază prin acela că li se asociază reprezentarea unor intensități deosebite (vezi mgh. kever 'amestecă' - kavar 'amestecă, împrăștie, spulberă', deged 'crește' - dagad 'crește, se umflă, k̈̈röm 'unghie' - karom 'gheară' etc.) (cf. Gombocz, 1997, p. 136).

${ }^{2}$ Spre exemplu, în rom. răvaş 'scrisoare, act, bilet' greu se mai recunoaște, dacă nu deloc, derivatul unguresc róvás 'răboj' din care provine (< ró- 'a scrie' + suf. subst. -(v)ás), iar termenul nici nu este un derivat în română. Tot așa, rom. răzăşs (răzeş) 'țăran liber, moșnean (în Evul Mediu, în Moldova)' a rezultat din adaptarea derivatului unguresc részes 'cel care are parte de/din ceva'(< rész- 'parte’ + suf. subst. -es), în română însă nu constituie un derivat (cf. și sămăraş, sechiraş etc.).
} 
care acesta o îndeplinește în cultura desemnatoare, locul pe care îl ocupă în sistemul socio-interpretativ, factorii cognitivi, afectivi etc. care determină interpretarea celui care întrebuințează semnul lingvistic, și, uneori, inclusiv samavolnicia arbitrară a diferiţilor indivizi, cum observă Bréal (1897).

În explicarea schimbărilor semantice, deseori se invoca „accidentul istoric”, considerîndu-se că evoluțiile de sens se produc în mod fatal și, uneori, lipsit de temei. Această modalitate de a se raporta la fenomenul schimbării semantice este combătută de Wundt (1904). În opinia psihologului german, schimbările petrecute în planul semnificatului nu sînt întîmplătoare, ci se conformează unor principii stricte, doar că nu întotdeauna se pot urmări procesele implicate. Astfel, autorul diferențiază două tipuri de schimbări semantice: regulate și sporadice. Primele reprezintă schimbări, în sensul strict al cuvîntului, fiind rezultatul unui proces statornic și lent, cauzele lor trebuind căutate în atributele conceptului supus schimbării, producîndu-se, deci, ca efect al unor modificări petrecute în asocierile mentale care funcționează la toți membrii unei comunități, asemenea unor acte instinctive. Schimbările sporadice, pe de altă parte, constituie situații de transfer care se produc spontan și fără etape de tranziție, pornindu-se, de regulă, de la anumiți indivizi ai colectivității și sînt rezultatul unor acte arbitrare. Cu alte cuvinte, cele dintîi reflectă istoria unui concept, pe cînd cele din urmă reprezintă, în primul rînd, istoria unui cuvînt și, pe urmă, istoria conceptului desemnat prin cuvînt. Neajunsul care i se poate reproșa acestei concepții constă în faptul că sensul (semnificatul) este privit de către autor ca fiind echivalent cu conceptul desemnat prin semnificant și, prin urmare, schimbarea semantică reflectă, așa cum afirmă W. Wundt, schimbarea conceptului. Or, sensul unui cuvînt se prezintă, mai degrabă, ca un concept funcțional și, ca atare, schimbările semantice trebuie văzute ca fiind schimbări ale semnificatului, produse adică în denotaţie (= semnificația lexicală curentă), iar nu în noțiune, cel puțin nu în mod absolut necesar (cf. Gombocz, 1997, p. 166). Cu toate acestea, W. Wundt are meritul de a fi introdus în discuția asupra schimbărilor semantice o modalitate de abordare nouă, care s-a dovedit extrem de utilă pentru cercetările ulterioare.

Cele mai multe clasificări ale schimbărilor semantice s-au rezumat la stabilirea punctului de plecare, adică al sensului de bază, și al punctului de sosire, adică al sensului derivat de la primul, nefiind însă în măsură să explice nici cauzele care au dus la trecerea de la un punct la celălalt, nici procesele implicate în acest demers, clasificările astfel obținute fiind, adesea, pur formale. Nici Paul (1886) nu se eliberează de o atare formalizare a descrierii. Tipurile de schimbări semantice pe care le disociază au în vedere raportul logic care există între sensul primar și cel derivat, diferențiind situații de supraordonare (extindere), subordonare (restrîngere) și coordonare (transfer metonimic). În ciuda utilității acestor concepte, problemele ridicate de evoluțiile semantice nu se epuizează prin acestea, cu atît mai mult cu cît aceste criterii nu explică și cauzele care declanșează schimbările sau, în orice caz, nu în toată complexitatea lor. Spre exemplu, se știe că o lărgire de sens își are punctul de plecare în existența, cel puțin, a unui sem comun, direcția în care diferitele sememe se dezvoltă nemaiaflîndu-se însă sub controlul unei regularități. Altfel zis, nimic nu impune prin sine ca un nucleu semantic să urmeze calea de dezvoltare a unei anumite nuanțe și nu a alteia. În cazul restrîngerii de sens, semnificatul își pierde unul sau mai mulți dintre sememii componenți, ceea ce, în majoritatea cazurilor, duce la specializarea lexemului la un anumit sem(em). Nici aici nu există însă motive de ordin lingvistic pentru alegerea unui anumit sem exploatat, ceea ce face ca schimbarea să fie impredictibilă. O altă contribuție valoroasă la cercetările de semantică diacronică o aduce Meillet (1905-1906, 1948), prin introducerea criteriilor socio-istorice în explicarea schimbărilor de sens. Astfel, autorul are în vedere complexitatea schimbărilor și dezvoltărilor culturii socioumane, a structurii sociale a comunității lingvistice, a stratificării limbilor în funcție de clase şi grupuri, urmărindu-se și efectele unora asupra altora. În realitate însă, și această interpretare cunoaște anumite limite, întrucît schimbările condițiilor culturale și sociale constituie doar una dintre cauzele posibile ale schimbării reprezentărilor și asocierilor mentale, fără a fi și necesare, iar raportul acestora cu procesele schimbării semnificatului este doar mijlocit. 


\section{Dezvoltările semantice ale unor împrumuturi maghiare în limba română}

La modul cel mai simplu, schimbarea semantică a unui cuvînt se poate descrie prin următoarea formulă: Ax > Axy > Ay (cf. Gombocz, 1997, p. 104), unde A reprezintă complexul fonetic căruia i se asociază o reprezentare mentală noțională x. În funcție de diverși factori, lui A i se poate asocia și un alt conținut, semnalat prin y, lucru posibil doar în virtutea existenței unei relații asociative între x și y. În sfîrșit, A se notează și cu înțelesul y, fie că Ax s-a uzat și s-a eliminat, fie că se păstrează atît Ax, cît și Ay. Atunci cînd se schimbă reprezentarea dominantă, adică conținutul noțional constant al unui cuvînt, se estompează și conștiința legăturii etimologice a cuvîntului, altfel spus, acesta își pierde legăturile cu ceilalți termeni cu care era înrudit semantic și/sau formal ${ }^{3}$.

Situaţia schimbărilor semantice observabile în cazul împrumuturilor maghiare din limba română se prezintă, și în acest caz, oarecum mai specială. Împrumuturile maghiare constituie produsul contactelor dintre cele două comunităţi lingvistice, astfel încît în ele se materializează, în fapt, cel puţin în momentul intrării lor în limba română, două universuri mai mult sau mai puțin diferite de reprezentări și asocieri mentale și emoționale.

În mod firesc, elementul preluat din limba maghiară isși păstrează la început sensul etimologic și în română ${ }^{4}$, după care poate trece prin evoluții semantice proprii, îmbogățindu-se cu sensuri diferite de cele din maghiară, uneori chiar eliminînd, parțial sau complet, sensurile originare sau, cel puțin, unele nuanțe ale acestora.

Nu este obligatoriu însă ca împrumutul să-şi dezvolte sensuri proprii în limba în care pătrunde, acesta putînd continua, la fel de bine, rețeaua de relații semantice din maghiară. Tot astfel, cauzele și căile prin care o anumită nuanță a unui semnificat-centru ajunge să aibă conotații pozitive sau depreciative sînt extrem de variate, iar explicația nu se limitează la condiții strict lingvistice. Modul de percepere psihosubiectivă a vorbitorilor determină, în mare măsură, atribuirea unei valențe conotate.

În tot cazul, mecanismele de generare a unor sensuri noi împrumuturilor maghiare sînt asemănătoare cu cele angajate în cazul oricăror altor cuvinte proprii limbii române (moștenite sau de alte origini). Vorbitorii împrumutători epuizează sensurile și contextele pe care un termen le oferă, cu atît mai mult dacă aceștia se află în contacte vii cu donatorii. Atît primii, cît și cei din urmă valorifică toate valențele unui termen, deși punctul final la care se ajunge într-una sau într-alta dintre limbi poate fi diferit. Capacitatea de producere a unor sensuri noi, uneori chiar deloc relaţionate cu sensul etimologic de bază, caracterizează atît bilingvii, cît și monolingvii, însă cei dintîi au posibilitatea de a valorifica într-o mai mare măsură valențele potențiale cuprinse în etimon. În același timp, ei rețin mai multe dintre nuanțele unui nucleu semantic și păstrează sensurile etimologice mai mult timp. La cei care nu se află în contacte directe și permanente cu vorbitorii maghiari, modificările operate se prezintă mai accentuat, iar termenul preluat se întrebuințează în accepțiuni și contexte mai limitate, cerute, evident, de propriile nevoi comu-nicative. De aceea, este cît se poate de firesc că, în cazul schimbărilor semantice majore, sensurile etimologice să se păstreze azi tocmai

\footnotetext{
${ }^{3}$ Spre exemplu, în cazul cuvîntului mgh. lábos 'cratiță’ deși conștiința legăturii etimologice nu s-a pierdut cu totul (< láb 'picior' + suf. subst. -as), în mod evident s-a schimbat reprezentarea noțională de altădată, cînd vasul de bucătărie se sprijinea, la propriu, pe picioare deasupra vetrei deschise (cf. MESz, s.v.). Cuvîntul mgh. szélhámos, la origine folosit adjectival, referitor la 'calul prins de marginea hamului și care alerga alături de caii care trăgeau căruța' (cf. MeSz, s.v.), astăzi 'impostor', pare săși fi pierdut atît legătura etimologică (szél 'margine' + hám 'ham' + suf. adj. -os), cît și reprezentarea noțională de bază (cf. și Gombocz, 1997, p. 110). Cea din urmă se putea estompa în rîndul acelor indivizi sau comunități care nu au avut relații îndeajuns de strînse cu lumea obiectuală implicată (căruțe și cai). Trecerea la sensul actual '(om) care înșală, amăgește' se poate explica prin proiectarea nuanței de 'aparență’ asupra altor realități obiectuale care au o înfățișare exterioară înșelătoare, întrucît calul astfel prins doar aparent trage căruța, derutînd, amăgind ochii/omul.

${ }^{4}$ Indiscutabil, toate împrumuturile își capătă sau își dezvoltă sensurile în mod dependent de sfera semantică a etimoanelor. În cazul unora, această dependență este decisivă și definitivă, împrumutul valorificînd exclusiv sau aproape exclusiv valorile semantice oferite în etimon, fără a-și pune la contribuție productivitatea proprie. În alte cazuri, împrumutul se eliberează de constrîngerile noționale ce derivă din cîmpul semantic pe care-l circumscrie etimonul și-și sporește, cu o forță (auto)generatoare spectaculoasă, sensurile proprii.
} 
în regiunile influențate, acum sau/şi în trecut, de către maghiarime, iar sensurile mai îndepărtate de cele cuprinse în etimon să se răspîndească în celelalte părți, puțin sau deloc afectate de influența maghiară. Firește, în majoritatea cazurilor, acestea din urmă au fost adoptate și de către limba română literară.

4.1. Direcția către care se împinge sfera semantică a unui împrumut pe terenul limbii primitoare poate fi cu totul diferită de cea de la care se pornește și pe care se raliază etimonul din limba donatoare. Un asemenea caz interesant îl constituie situația termenului rom. adămană (< mgh. adomány 'donatio, donum', MNYSZ, cf. EWUR, p. 54; forma cu -ă decurgînd dintr-o variantă morfologică, probabil, din cea cu sufixul posesiv -(j)a). Împrumutul românesc de origine maghiară și-a dezvoltat un sens cu totul deosebit de cel al etimonulului, plasîndu-se, astfel, într-o altă sferă conotativă. În limba maghiară, adomány are semnificația 'donație,' 'tot ce i se acordă cuiva în dar sau drept recompensă, ceea ce implică rolul unui beneficiar, altfel spus, o notă pozitivă. Rolurile tematice se schimbă oarecum în rom. adămană care, în textele românești vechi, se întrebuințează cu înțelesul 'camătă, dobîndă': „Argintul său nu va da într-adămană și plată nu va loa de la nevinovați”" ( $\left.\mathrm{PH}, 9^{\mathrm{v}} / 5\right)$. Astfel, sensul împrumutului presupune existența unui debitor, implicînd, deci, o notă negativă. Sensul 'camătă, dobîndă se păstrează și în secolele următoare, în Transilvania, în Maramureș (SD, s.v.) şi Oaș (CADE, s.v.). Termenul a evoluat, probabil ulterior, și către o nuanță de 'mită, tentație' (semnalată în CADE, SD, DLRLV, unde vezi și var. ademană), semnificație din care s-a putut dezvolta și sensul actual al derivatului verbal a ademeni 'a înșela', 'a ispiti, a tenta' și chiar 'a seduce' (SD, DA, DER, TRDW, s.v.). Spre deosebire de situația sensurilor dezvoltate pe terenul limbii române de la sensul derivat al semnificaţiei cuprinse în etimonul maghiar, care sînt perfect explicabile unele din altele, explicarea trecerii de la sensul primar, etimologic, la cel derivat întîmpină unele dificultăți. Ce se poate observa este că, în maghiară, substantivul adomány își valorifică valențele verbului de atribuire de la care s-a derivat: ad 'a da' + suf. subst. -(o)mány (cf. și ír 'a scrie' + -(o)mány). O asemenea segmentare componențială putea fi operată încă, deși nu în mod absolut necesar, de bilingvii împrumutători care puteau fi familiarizați cu acest procedeu de formare a cuvintelor în limba maghiară, respectiv care aveau nenumărate oportunități de raportare și de ajustare (control) a elementului străin chiar în sursa proprie a acestuia. Însă, în lipsa unor contacte directe cu maghiarii sau, pur și simplu, supus factorului timpului, termenul rom. adămană se prezenta ca fiind neanalizabil din punct de vedere lexical, întrucit, în română, componentele sale nu au semnificaţia pe care o aveau în etimon. Astfel, nu numai că s-a rupt legătura etimologică, dar s-a pierdut și reprezentarea mentală dominantă, cuprinsă în etimon. Este însă greu de stabilit care este cauza precisă care a împins semnificația într-o cu totul altă direcție decît cea a etimonului.

4.2. O altă situație ne apare în cazul rom. a adăvăsi (der. rom. < mgh. odavesz-ni 'pereo; zu grundé gehen', MNYSz - 'a dispărea', 'a se pierde din vedere', 'a (se) mistui' + suf. verbal - $i$; cf. N. Drăganu, DR, IV, 1924-1926, partea 2, p. 752-753; cf. EWUR, p. 55-56). Sensul primitiv al verbului a fost, cel mai probabil, 'a risipi, a împrăștia', cu care se întrebuințează în secolul al XVI-lea. Astfel, cu sensul 'a prăpădi un popor', termenul este notat în PO: „Împărți-voiu pre ei în Iacov și voiu adăvăsi în Izdrail” (Gen, 49, 7). De la acest sens general 'a irosi', adjectivul adăvăsit a căpătat înțelesul 'împrăștiat, cheltuit, epuizat', cu care apare într-o notă din GB $\left(271^{\mathrm{v}} / 1\right)$, în care corespunde sl. dospěti 'obosit, ostenit' (cf. și Pamfil, 1958, p. 234). Cu un sens apropiat, însemnînd 'a (se) extenua, a consuma, a (se) istovi' el se regăsește și în secolul următor, cunoscînd o repartiție în Transilvania de nord și în Moldova (cf. DLRLV, s.v., unde vezi și var. adevăsi). De la nucleul 'a risipi (averea)' s-a putut ajunge la sensul 'a cheltui, a prăpădi', atestat în Moldova (cf. DA, s.v.). Cu acest din urmă înțeles, termenul se întrebuințează și azi în unele regiuni din Transilvania și Oltenia (Pamfil, 1958, p. 234). Accepțiile, mai mult sau mai puțin distincte ${ }^{5}$, cu care termenul se atestă în Transilvania au toate semnificația comună 'a înceta, definitiv sau momentan, să existe sub forma inițială', fie că se referă la ființe - 'a (se) pierde, a (se) nimici, a prăpădi, a dispărea' - fie la bunuri materiale—'a risipi, a consuma, a cheltui, a irosi' etc. În toate aceste cazuri, schimbarea unei stări de fapte duce la o situație

\footnotetext{
${ }^{5} \mathrm{Cu}$ sensul 'a prăpădi, a risipi' în Alba; 'a dispărea' în Bistrița-Năsăud, unde vezi și var. adevesi 'a pierde' (Lex. reg., II, 75); a dăvăsi 'a se pierde' în Maramureș; a devăsi 'a se risipi, a se pierde, a se strica' în j. Sibiu (Lex. reg., II, 59); a devesi 'a face risipă de ceva, a irosi’ în j. Brașov; a tăvăsi ‘a prăpădi’ în Munții Apuseni (cf. Gheție \& Mareș, 1974, p. 263).
} 
deficitară, care înregistrează o pierdere, un minus. Spre deosebire de aceste nuanțe, regăsite și în maghiară, limba română notează și un sens opus celui iniţial, și anume 'a aduna, a strînge', în Iaşi (Lex. reg., I, 63); iar adevesesc 'tocmesc', probabil, în Vaslui (cf. Gheție \& Mareș, 1974, p. 263).

4.3. Așa cum s-a menționat, sensul lexical este, probabil, cel mai încărcat de gîndire (Gafton, 2010, p. 84) și, în același timp, de afectivitate. Elementele lexicale sînt purtătoare a modului de conceptualizare a lumii, a modului de raportare la aceasta și, în același timp, sînt impregnate de sensibilitatea, de trăirile emoționale care caracterizează o comunitate lingvistică și pe care vorbitorii unei limbi și-o asumă, voit sau involuntar, prin apartenența la un grup etnic și lingvistic. Altfel spus, lexemele funcţionează ca niște vehicule în care se depozitează (și) predispozițiile emoționale, volitive proprii unei colectivităţi, ca niște „exponente” lingvistice ale universului de spiritualitate al acesteia. De asemenea, trebuie observat că sensul lexical și complexul fonetic, prin sonoritatea acestuia, adesea converg, purtînd același conținut emoționalspiritual. Această stare de fapte explică, într-o oarecare măsură, acele schimbări semantice petrecute pe terenul limbii-țintă care ne apar nemotivate sau, în orice caz, mai puțin justificate din punct de vedere lingvistic. În aceste cazuri, schimbările semantice sînt dintre cele mai spectaculoase şi mai interesante, întrucît universul emoțional este rareori preluat o dată cu termenul împrumutat. În aceste condiții, o soluție firească este acea de a adapta conținutul afectiv conform sensibilității și spiritualității proprii vorbitorilor care împrumută.

Pentru cele expuse, elocventă este situația rom. bănat (<mgh. bánat 'tristețe, jale, durere, regret'; cf. Mândrescu, 1892, p. 134-135; cf. EWUR, p. 99-100; cf. DER, s.v.). În secolul al XVI-lea, termenul este atestat cu sensurile 'supărare, mîhnire, necaz, durere, scîrbă', 'tristețe, jale, părere de rău', consemnat în PH, cu numeroase ocurențe: „Bănat și lî̀ n > goare aflaiu” (100²/3), „Bănat și nevoi aflară-me” (108 r/143), „,ănatulu e aproape, că nu e cinre se-mi agiute” (17 $/ 12)$, „Multe bănaturi derepților și de toate-i va izbăvi ei Domnulu" (28 $/ 20)$, intrînd și în sintagme ca: întru bănatu (2 $\left.2^{\mathrm{v}} / 2\right)$, de tot bănatul $\left(20^{\mathrm{v}} / 22\right)$, de la toate bănaturile $\left(27^{\mathrm{v}} / 5\right)$, in vremea bănatului $\left(32^{\mathrm{v}} / 39\right)$, în mijloc de bănat $\left(117^{\mathrm{r}} / 7\right)$. Interesant se prezintă felul cum termenul și-a lărgit sfera semantică, de la nucleul 'regret, melancolie', regăsit în maghiară, la nuanțele 'dor, supărare, mîhnire', 'pică, mustrare', cu care se notează în limba română. Explicația trebuie căutată, credem, în spiritualitatea diferită a popoarelor român și maghiar.

Astfel, de pildă, se poate observa că poporul maghiar se caracterizează printr-o predispoziție către lamentație, melancolie, printr-o viziune a lumii pictată adesea în tonuri grave, sumbre. Această sensibilitate este reflectată, prin excelență, în cuvîntul mgh. bánat (<vb. bán-ni 'a regreta (în special, acțiunile proprii)' + suf. subst. - at) care, prin sensul său lexical de 'tristețe, jale, părere de rău', circumscrie un univers meditativ, pătruns de sobrietate. Complexul sonor, la rîndul lui, asigură, în plan fonetic, tonalitatea gravă, prin alternarea perechii vocalice $[a]-[a ́]$, impusă de armonia vocalică. Acest din urmă aspect nu se valorifică în împrumutul românesc, în limba română neexistînd diferențierea vocale joase vs. vocale înalte, care reglementează armonia vocalică.

Sfera semantică a substantivului unguresc pare să circumscrie o stare de spirit caracterizată prin neputință, regăsită, parțial, și în sensurile termenului românesc. Alături de această notă, sensul termenului maghiar cuprinde și o dimensiune etico-morală și religioasă, cuvîntul bánat denotînd și ' tristețea, regretul, sentimentul de culpabilitate resimțit de un credincios pentru păcatele sale, căință’ (Czuczor \& Fogarasi, s.v.). Această notă trimite la autoexaminare, ceea ce presupune o interiorizare a trăirii. Această semnificaţie nu este cu totul străină nici împrumutului românesc, ea fiind regăsită, în special, în uzul din medii bilingve, puternic influențate de maghiarime. Astfel, bănat se notează, încă din secolul al XVI-lea, cu sensurile 'tristețe, jale, regret', cunoscînd o repartiție în Banat-Hunedoara. Aceste sensuri sînt reținute și în secolul următor în Moldova, în Crișana, în Transilvania de sud-vest și în Transilvania de nord (cf. DLRLV, s.v.). $\mathrm{Cu}$ toate acestea, nota 'căință' pare să se plaseze pe o poziție periferică față de celelalte sensuri dezvoltate independent de etimon. Lucrul acesta s-ar putea susţine prin faptul că deseori rom. bănat este semnalat cu sensuri care trimit către o exteriorizare a emoției, către proiectarea ideii de 'vină' asupra lumii exterioare. $\mathrm{O}$ asemenea direcție par a circumscrie sensurile, precum: 'ciudă, pizmă, 'bănuială (DER); 'mînie, supărare', 'bănuială, prepus' (sD, s.v.); 'mîhnire, supărare', 'mînie, necaz, ciudă', învinovățire, imputare, mustrare, 
certare', 'bănuială, suspiciune' (cf. DLRLV, s.v.), înregistrate în diferite dicționare românești. Oricum ar sta lucrurile, coexistența notelor de 'reflecție asupra sinelui' și de 'proiectare asupra celuilalt', pe care le prezintă termenul românesc ${ }^{6}$, ni se pare destul de curioasă.

4.4. Fiind derivat de la aceeași rădăcină ca și termenul precedent, în aceeași categorie ar putea fi discutat și cazul rom. a bănui (der. rom. < mgh. bán-ni 'a regreta' + -ui; cf. Mândrescu, 1892, p. 136-137; cf. EWUR, p. 100-101). Împrumutul prezintă o bogată dezvoltare semantică pe terenul limbii române, îmbogățindu-se cu sensuri neîntîlnite în etimonul unguresc. Astfel, verbul românesc este întrebuințat în psaltirile românești vechi cu înțelesul etimologic 'a se căi, a regreta', 'a-i fi jale, a fi necăjit', notat, de pildă în PH: „Cătră Domnul cîndu bănuiiu chemaiu și me audzi” (109 / 1), „Nu întoarce fața ta de la fătul tău, / că bănuiescu; curru $<\mathrm{n}>\mathrm{du}$ a $<\mathrm{u}>\mathrm{dzi}$ me” $\left(58^{\mathrm{v}} / 18\right)$, ,așteptaiu cinre e $\boldsymbol{s}$ e bănuiască și nu fu” ( $\left.58^{\mathrm{v}} / 21\right)$, „În porîncitele tale bănuiiu și înțeleșu caile tale" $\left(102^{\mathrm{v}} / 15\right)$. Semnificația originară de 'a (se) întrista, a-i părea rău, a se căi, a regreta' este reținută și în secolul al XVII-lea, repartizarea acesteia cuprinzînd Moldova, Banatul, Crișana și Trans. sud-vest (cf. DLRLV, s.v.), și este păstrată și azi în unele regiuni ardelenești (cf. ILR I, p. 242). Nucleul semantic 'regret' cuprinde o serie de nuanțe, printre care: 'a fi pradă grijilor, durerii, a se simți trist' $\left(\mathrm{PH}, 58^{\mathrm{v}} / 18,21\right)$, 'a-și da osteneala, a arăta o grijă deosebită pentru îndeplinirea unui lucru' ( $\left.\mathrm{PH}, 102^{\mathrm{v}} / 15\right)$, regăsite și în maghiară. Pe terenul limbii române, sfera semantică a acestuia s-a lărgit însă, îmbrățișind și nota 'a (se) lamenta', exprimînd o nemulțumire, care a dus la dezvoltarea unor sensuri noi. Astfel, în secolul al XVII-lea, termenul se consemnează cu înțelesurile 'a-i lua (cuiva ceva) în nume de rău, a se mînia, a se supăra, a se indigna' în Moldova şi Țara Românească, iar în Țara Românească și în Transilvania sud-vest se înregistrează și înțelesul 'a suspecta'. Termenul este atestat în acest secol și cu sensurile figurate 'a cîrti' (Moldova) și 'a pizmui, a invidia' (Țara Românească) (cf. DLRLV, s.v.). Astăzi rom. a bănui înregistrează, alături de întrebuințările regionale 'a fi cuprins de regret' (CADE, s.v.), și sensurile 'a înainta pretenții cuiva', și 'a se simți jignit, a se ofensa' (DER, s.v.). În utilizarea tranzitivă, verbul a ajuns să însemne 'a avea o părere proastă; a reproșa, a face mustrări', de la care s-a putut dezvolta sensul actual uzual 'a presupune, a presimți, a-și închipui despre cineva un lucru nefavorabil'. Prin urmare, deși sensul primitiv se plasează la o oarecare distanță de sensurile derivate 'a suspecta, a pune la îndoială', 'a presupune drept vinovat sau condamnabilă o persoană sau o acțiune', acestea nu rămîn fără putință de a le (re)lega ${ }^{7}$.

4.5. Un alt termen care intră în familia lexicală a verbului mgh. bán-ni 'a fi necăjit, a regreta' este forma factitivă a acestuia, bánt-(a)ni 'a-i produce cuiva necaz, a vătăma, a răni, a-i face rău' (cf. MESz, s.v.), care a dat în română a bîntui (cf. Mândrescu, 1892, p. 136; cf. EWUR, p. 126; cf. DER, s.v.). Termenul românesc a fost fie explicat prin etimologie multiplă, acesta fiind regăsit și în limbile slave (vezi bantovati), fie introdus în seria verbelor în -ui și explicat prin filieră slavă. Limba română în contact cu ambele limbi putea însă împrumuta acest cuvînt fie din una, fie din alta, fie chiar din ambele, în funcție de diferite regiuni sau în mod repetat, în perioade diferite (cf. Arvinte \& Gafton, 2007, p. 97). În zonele de contacte permanente cu populația maghiară, nu ar fi greșit să se presupună că românii au împrumutat acest cuvînt de la unguri.

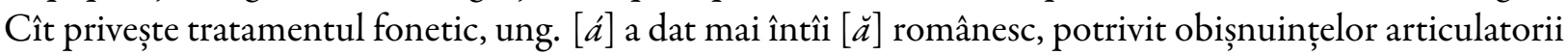
ale limbii române, iar ulterior a trecut la $[\hat{\imath}]$,pentru că înainte de $[n]+$ consoană a fost mai obişnuit” acesta din urmă (Király, 1990, p. 118) ${ }^{8}$. În sfîrșit, sufixul -ui i-a fost adăugat pe teren românesc (cf. a făgădui, a tăgădui etc.).

Diferitele note, mai mult sau mai puțin distincte, cuprinse în sfera semantică a verbului $a$ bîntui se acumulează în jurul ideii centrale 'a răni, a vătăma', producînd, așadar, efecte nedorite, pagube. Acesta constituie, de altminteri, și nucleul semantic al etimonului maghiar bánt-a-ni care înregistrează nuanțele asociate 'a răni, jigni, a supăra, a enerva, a perturba', '(cu referire la fenomene ale naturii) a păgubi' sau

\footnotetext{
${ }^{6}$ Printre sinonimele cuvîntului bănat, dicționarele amintesc: amărăciune, întristare, tristețe, necaz; mîhnire, supărare, dar și admonestare, ceartă, certare, dojană, dojenire, mustrare; ciudă, gelozie, invidie; neîncredere, bănuială, suspiciune; învinuire, imputare; pică, pizmă, pornire, ranchiună, reproș; vină.

${ }^{7}$ Nota negativă 'a disprețui' poate fi surprinsă deja în PH (58 / 18) (cf. Rosetti, 1931, p. 147).

${ }^{8}$ Aceeași prefacere a lui $[\breve{a}]$ în $[\hat{\imath}]$ are loc și în rom. intîlni < (în)tălni < ung. találni, dar și a lui $[e]$ neaccentuat în poziție nazală (cf. mgh. menteni > rom. măntui > mîntui), ca, de altfel, și în cazul cuvintelor moștenite.
} 
'(despre boli) a chinui' (cf. Czuczor \& Fogarasi, s.v.). Termenul este atestat în secolul al XVI-lea cu sensul etimologic 'a răni, a-i face rău', consemnat în documente din toate cele trei principate românești: „nime să nu-1 bîntuiască preste cartea mea” (Dî, XLI, 5, ${ }^{*}$ Trans.), „ne-au băntuit în slujba noastră” (Dî, XLIV, $237^{\mathrm{V}} / 8$, ${ }^{*}$ Mold.), „nime să n-aibă $\boldsymbol{a}$-i bîntui preste dzisa noastră” (Dî, CX, 8), unde vezi și der. bîntuială 'a vătămare’: „,̦i de nimea bîntuială să nu aib[ă] niciodată” (Dî, XXXIX, 1²/15). Această semnificație este notată și în veacurile următoare.

Deși sporadic, limba română veche înregistrează și sensuri mai apropiate de întrebuințarea actuală, consemnînd, de pildă, sensul 'a se arunca asupra ceva' $\left(\mathrm{CC}_{1}, 172\right)$ (cf. ILR II, p. 269). Uzurile românești de azi par să insiste asupra intensității pagubelor produse, cuvintul ajungînd să însemne '(despre forțele naturii) a lovi insistent și cu violență, '(despre boli, războaie, năvăliri) a pustii, a devasta, a face ravagii', '(despre fințte) a împila, a asupri'. Regional, cuvîntul apare și în imprecații: Să (mă) bîntuie (Dumnezeu) 'a pedepsi, a bate' (cf. DEx, '98, s.v.). După cum se vede, spre deosebire de conotațiile mai delicate din maghiară, unde verbul exprimă, în majoritatea contextelor, 'deranj, neplăcere' (cf. sérelem, szomorúság, Czuczor \& Fogarasi, s.v.), limba română a dezvoltat nuanța mai intensă 'devastare', prin exacerbarea valențelor virtual cuprinse în etimon. Tot pe terenul limbii române s-au dezvoltat și sensurile '(despre spirite) a cutreiera', 'a chinui, a munci de duhuri necurate', respectiv 'a ispiti' (cf. CADE, s.v.).

4.6. Un alt caz pe care îl avem în vedere este cel al rom. gînd (< mgh. gond 1. 'cura,' 'sorge', 2. 'cogitatio', MNYSZ; cf. EWUR, p. 386; cf. DER, s.v.), destul de larg întrebuințat în limba română veche? . Cu toate că mai rar, în literatura de specialitate, s-a propus pentru mgh. gond > rom. gînd ipoteza filierii slave (vezi Pușcariu, 1940, p. 299). O intermediere slavă, deși posibilă, nu este însă necesară, forma românească fiind perfect explicabilă din etimonul unguresc, dacă se au în vedere principiile adaptării fonetice a împrumuturilor maghiare. Astfel, pentru trecerea lui $[o]$ la [î] , în cazul acestui cuvînt, filiera slavă nu este unica soluție posibilă, căci în română $[o]+[n, \mathrm{~m} \mathrm{l} . \mathrm{r}]+$ o altă consoană $>[\breve{a}]>[\hat{\imath}]$ și în alte cuvinte în care slava n-a jucat nici un rol.

În ceea ce privește evoluția semantică a acestui termen, se poate observa că între sensul etimonului gond și înțelesurile, vechi și noi, ale împrumutului gînd se plasează o distanță considerabilă (cf. și ILR I, p. 242 $)^{10}$. În maghiară, substantivul denotă 'o conștiință tulburată, 'cuget pătruns de neliniște', asociind, deci, intelectul cu emoții (cf. bizonyos nyugtalansággal és kedvetlen érzéssel, aggálylyal párosúl, Czuczor \& Fogarasi, s.v.). Și celelalte sensuri ale lui gond—vezi 'grijă' sau 'precizie, exigență’ (cf. MESz, s.v.) -sînt, de fapt, conotate afectiv. Spre deosebire de această stare de fapte, în română, gînd a pătruns cu o valoare emotivă neutră, desemnînd 'cuget, minte, conștiință. Astfel, în CV se consemnează 'conștiință, cuget' ${ }^{11}$ : „Bărrbaţi frați, eu cu totu gîndul cela bunrul viu” (23/2-4), „nevinovatu gîndu aibîndu” (31 $\left.{ }^{\mathrm{r}} / 6-7\right)$, „cu gîndurele cealea bunrele” (78v $/ 12-13)$; cu înțelesul 'cuget' apare și în Св: „curatului gîndu” $(2 P, 3,1)$; și în documente: „acel svat și acel gîndu” (Dî, XCIII, $1^{\mathrm{r}} / 6$ ), unde vezi și var. ghendul (Dî, C, 82 $/ 11$ ). Acest înțeles, deși prezent în gond (cf. MNYSz, s.v.), redă, mai degrabă, nucleul semantic al derivatului unguresc gondolat. Limba română a dezvoltat apoi şi alte sensuri, precum: 'înțelepciune', notat în PH: „ciudele tale, și cu gîndurile tale nu e cinre se va asăm<ă >na ție” ( $\left.34^{\mathrm{r}} / 6\right)$; 'prevedere, înțelepciune' în CV: „Multă lume nemereaște cu tinre și isprăvire easte limbiei aceștiia cu ale tale gîndure” (29 $\left.\left.9^{\mathrm{r}} / 7-11\right)^{12}\right)$; 'intenție' în PH: „tu înțeleseși gîndul mieu de departe” (117\%/3), cf. și în loc. vb. a umbla cu gîndul: „în casa

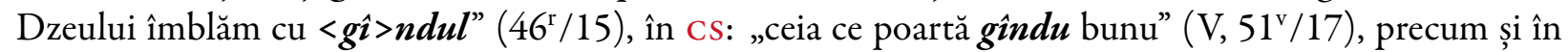
documente, în special, ardelenești și moldovenești: ,gîndul și voia gărdinarului” (Dî, XXXVI, 249²/10,

\footnotetext{
91̂n textele românești vechi care cuprind traduceri din Vechiul Testament, nu există o „normă lexicală individuală unică” şi colectivă pentru conceptul 'conștiință'. La nivelul fiecărui text se poate observa însă tendința către edificarea unei asemenea norme. Astfel, la Coresi, spre exemplu, asemenea CV, acolo unde în textul-sursă slavon apare termenul care redă ideea 'conștiință', acesta este tradus, generic, prin gînd (Munteanu, 2008, p. 370).

${ }^{10}$ Autorul sesizează deosebirea semantică între gond 'îngrijorare' și gînd 'cuget, idee', deși observă că termenul maghiar înseamnă și 'cuget', notat în dicționare maghiare (mai ales sub forma gondolat).

${ }^{11}$ Corespondent al lui sfeat (uri) la Coresi.

${ }^{12}$ Cf. cugetat la Coresi.
} 
Trans.), ,i-au fost gindul cum mă va piiarde” (Dî, XLIV, 237 / 12, Mold.); 'ostentaţie, pompă', 'imaginație', 'înșelătorie' în CV: „Venre Agripa și Vernichie cu multu gîndu” $\left(36^{\mathrm{r}} / 4\right)^{13}$. Termenul românesc notează și 'grijă, îngrijorare, bănuială, intenţie' (cf. Niculescu, 2005, p. 120). Uzurile actuale au lărgit sfera semantică a cuvîntului, desemnînd prin gînd 'idee,' 'meditație, reflecție,' 'opinie, părere, 'spirit, inteligență (cf. DER, s.v.).

4.7. Intensificarea unei nuanțe semantice virtual cuprinse în etimon se prezintă cu totul aparte în cazul rom. a faggădui (der. rom. < mgh. fogad-ni 'a primi, a găzdui', și 'a promite, a încredința', mai ales cu prefixul verbal meg-fogad, + -ui; cf. Mândrescu, 1892, p. 151-153; cf. EWUR, p. 319; cf. DER, s.v.) care ocupă o poziție însemnată printre împrumuturile maghiare vechi, ca frecvență, diversitate semantică, bogăție a formelor flexionare și a derivatelor.

Verbul unguresc fogad-ni cuprinde în sfera sa semantică numeroase nuanțe concentrate în jurul a două nuclee semantice: 1. 'a primi (în casă pe cineva)', implicînd și o oarecare 'bunăvoință, ospitalitate' (cf. bizonyos kedvvel, kedélylyel lát, Czuczor \& Fogarasi, s.v.) și 2. 'a promite, a se angaja la îndeplinirea unei promisiuni'. Împrumutul a făgădui, în limba română, nu continuă toate înțelesurile, ceea ce nu este deloc neobișnuit. Curios este însă faptul că, deși ambele centre semantice sînt prezervate și în română, se inversează rangul acordat acestora în cadrul limbii împrumutătoare faţă de cea donatoare. Astfel, în limba română actuală, sensul uzual al verbului, cu care acesta se întrebuințează aproape în mod exclusiv, aparține sferei semantice 'promisiune', iar 'a primi (în gazdă)' a devenit un sens ocazional ${ }^{14}$, în special regional.

Termenul este înregistrat în textele românești vechi deosebit de nuanțat. Astfel, sensul etimologic 'a primi (în casăa)' este notat în CV: „Și deca fumu noi întru Ierusalim, cu iuboste făgăduiră noi frații” $\left(14^{\mathrm{v}} / 14-15^{\mathrm{r}} / 1-2\right)$; tot etimologic este și sensul 'a găzdui, a da sălaș' în CS: „de se nu-l făgăduimu elu” (XV, 122 16 ), respectiv 'a primi, a accepta' în PS: „Audi Doamne dereptate me, făgăduiaște rugăciure me” $(16,1)$. Notele particulare de 'benevolență, cordialitate' asociate acestuia au înlesnit dezvoltarea nuanței 'supunere', ducînd la înțelesul 'a asculta pe cineva, a urma sfatul', consemnat în PO: „Și frații lui luară și făgăduiră lui cuvîntul” (Gen, 37, 27). De altfel, verbul unguresc cuprinde și el printre valorile sale nota distinctivă 'a accepta cu succes, dînd roade' (cf. valamit sikeresen, gyümölcsözöleg vesz magába, Czuczor \& Fogarasi, s.v.). În română, aplicabilitatea acestei consimţiri roditoare se extinde însă numai asupra interiorizării 'cuvîntului', spre deosebire de maghiară, unde, pe lîngă 'obediență (cf. expresia szót fogadni), se regăsește și ideea 'fertilitate', altfel zis, 'a primi în pîntece un făt' (cf. gyermeket mébbe fogadni, Czuczor \& Fogarasi, s.v.). În mod interesant, această nuanță, regăsită cu o frecvență deosebită în versiunea maghiară a PO (vezi fogada és szüle 'concepu și născu'), nu se păstrează în română, fiind redată printr-un alt împrumut, însă tot de origine maghiară fu tăroasă $(G e n, 4,1)$. În aceeași sferă semantică ar putea fi inclus și sensul dezvoltat 'a lua de soț' în Св: „se făgăduiască soț pre soțu” (Fap, 19, 38).

Pornind de la celălalt nucleu semantic 'angajament', acesta cunoaște, la rîndul lui, diverse grade de intensitate în textele românești vechi. Verbul notează 'a promite’ în FRAG.TOD.: ,făgăduit-ai noauă că ne vei slobodzi” (4r/27), ca și în PO: „cum Domnul lu Avraam să dea cea au făgăduit lui” (Gen, 18, 19) ${ }^{15}$; cu sensul 'a promite, a jura' apare în PH: „Că se giură / Domnului <și > făgădui-se lu Dumnedzeu” (113\% /2), în CB: „, si făgădui să dea lui” $(F A, 7,5)^{16}$ etc. În alt loc, termenul desemnează luarea de angajament față de divinitate, precum în CS unde forma reflexivă ${ }^{17}$ este întrebuințată cu înțelesul 'a se ruga, a jura credință': "Acesta sîntu cei ce s-au botedzat și se-au făgăduitu cruciei” (IV, 31 1 /12).

\footnotetext{
${ }^{13}$ La Coresi, amegire. Apostolul coresian întrebuințează, în alt loc, cugetat (29 $\left./ 7-11\right)$, sfeat (23v /2-4).

${ }^{14}$ De altminteri, s-a propus și posibilitatea de a considera cele două sensuri drept actualizări semantice a doi termeni omonimi: a făgădui 'a primi în casă (ca oaspete)' și a făgădui 'a promite’ (cf. Graur, 1954, p. 127). Cu toate că veriga de legătură între sensuri este, poate, mai greu de refăcut, distanța între acestea nu este însă de netrecut. Prin urmare, nu credem că ar trebui să se separe cele două nuclee semantice, ambele fiind regăsite în secolul al XVI-lea.

${ }^{15}$ Aici redă perifraze ung. cu igirte, igiret 'promisiune'.

${ }^{16}$ Prezența lui cu acest sens arată o opțiune deliberată a autorului pentru acest termen deoarece în limbă existau și alte sinonime, cum reiese din alte versiuni ale fragmentului, vezi a giurui (CV), a jura (CP).

${ }^{17}$ Verbul, la origine activ tranzitiv, a devenit reflexiv în limba română prin acomodarea la alte verbe (cf. a se apuca, a se angaja) cu sensul 'a promite' (Mândrescu, 1892, p. 151-152).
} 
De asemenea, împrumutul dă dovadă de o vitalitate extraordinară, dezvoltîndu-și numeroase derivate, precum: subst. făgăduit în PS.C.: „pus'ai lacrîmele mele între tine, că în făgîduitulŭ tău” (55/15); adj. făgăduit 'promis' în $\mathrm{CC}_{2}$ : „pămîntului făgăduit” (7/5-6); subst. făgăduită ‘făgăduială în PH: „pus-ai lacrămile meale între tinre ca în făgăduita ta” (47²/9); faggăduită 'jurămînt' în СB: „să nu împarță-se, ce ca așteapte făgăduita Tatălui" (Fap, 1, 4) ${ }^{18}$, unde vezi și var. făgădoita (Fap, 2, 33); subst. fägăduitură 'făgăduință, promisiune' în CAT.C.: „că toate făgăduiturile lui Dumnezeu cu credință numai să le putem cuprinde la noi” $\left(10^{\mathrm{r}} / 1-5\right)$ și în CS (XII, 105 $\left./ 16-105^{\mathrm{v}} / 4\right)$; inf. lung fägăduire(a) în Св: „ceia ce părințiilorune făgăduirea ce fost-au” (Fap, 13, 32); der. subst. fägăduială: „porunca împăratului și făgăduiala ce ne-au fost trimese" (Dî, XXXI, 253\% /10). Termenul intră și în compuse, precum: bun(r)ă-făgăduită în CV: „a rădica cumîndare Duhului bunră-făgăduită Dzeului Isus Hristos” (73 $/ 9-11)$ și în CB: „bunăfăgăduitele lu Dumnezeu" (IP, 2, 5). Alte derivate vezi în CADE, SD.

După cum s-a arătat, în secolul al XVI-lea, termenul cunoaște o largă întrebuințare, cu repartizare, în special, în nord- și sud-vestul Transilvaniei. În secolul următor, verbul, cu sensul 'a primi, a lua în considerație', cunoaște o repartiție în Trans. sud-vest; der. subst. făgăduială 'promisiune' în Țara Românească, iar der. subst. făgadă 'primire, acceptare' și 'promisiune’ în Moldova (cf. DLRLV, s.v.). Astfel, maghiarismul se conforma, cel mai probabil, normei lingvistice comune din secolul al XVI-lea. Acesta s-a păstrat și în limba literară contemporană (în special, cu sensul 'a promite'), ceea ce se poate datora (și) faptului că, fiind cunoscut încă din texte biblice, acesta poartă în sine o stare de spirit învăluită de sacralitate și o tradiție care, deși concurate de rivali neologici (în special, francezi-vezi a promite), nu au putut fi înlăturate.

4.8. Diversificarea sensurilor dobîndite pe terenul limbii române se prezintă interesantă și în cazul împrumutului a (se) tămădui (der. rom. < mgh. támad-ni 'oborior, exsurgo'; 'entspringen, aufstehen', MNySz, + -ui; cf. Mândrescu, 1892, p. 185; cf. EWUR, p. 769-770; cf. DER, s.v.), care a dezvoltat o sferă semantică deosebită de cea a etimonului său. Deși explicarea trecerii de la un sens la altul se împiedică de unele obstacole, prăpastia care desparte înțelesurile verbului unguresc de cele ale cuvîntului românesc este doar aparentă.

Sensul primitiv din limba maghiară a lui támad-ni este 'a se ridica, a răsări', de unde putea fi derivat înțelesul uzual de azi 'a se ridica împotriva cuiva, a se răscula'. În limba română veche, cuvîntul este însemnat cu înțelesul 'a (se) vindeca, a (se) lecui', regăsit și în der. subst. tămăduire: „Se fie iarba la tămăduire, aceaea ainte de covrag și secă” ( $\left.\mathrm{pH}, 112^{\mathrm{v}} / 6\right)$, adj. tămăduit: „ „ŞSi > oameri tămăduiți lăuda-vor Domnulu” ( $\left.\mathrm{PH}, 84^{\mathrm{r}} / 19\right)$, care poate reprezenta o continuare a sensului etimologic, cu completarea 'a se ridica dintro boală ${ }^{19}$. Explicarea sensului 'a crea' cu care se găsește notat în PH: „Înrimă curată tă/măduiaște întru menre” (43\%/12), „Trimite-veri aburul lor și se vor tămădui” $\left(87^{\mathrm{v}} / 30\right)^{20}$ oferă mai puțină certitudine. Acesta pare a reproduce sensul etimonului 'a se ivi, a lua naștere' (cf. ered, keltezik, Czuczor \& Fogarasi, s.v.), cu care termenul putea fi circulat regional, cu toate că alte atestări ale acestui sens nu avem. Termenul se mai găsește consemnat în secolul al XVI-lea și cu sensul 'a zidi' ${ }^{21}$ în PH: „Și se tămăduiască-se păreții” (43v/20), și în CP: „Rugă ei cum să se tămăduiască și să lăcuiască în pridădirea credințeei” (Sp. la Iuda) $)^{22}$, care poate duce mai departe sfera semantică dezvoltată în maghiară de 'a sprijini (în ridicare)' (cf. felemelkedve megtámogat, alátámaszt jelentéskör, $\mathrm{MeSz}$, s.v.).

În limba română actuală, contextele semnalate în care apare verbul includ ideea 'boală. Astfel, în întrebuințările lui tranzitive și reflexive, sensurile uzuale 'a (se) vindeca, a (se) lecui' (cf. DER, s.v.) cunosc nuanțele 'a se îndrepta, a reveni la starea normală (după o boală)', '(despre răni) a dispărea în urma unui tratament', '(despre stări sufletești apăsătoare) a înceta de a se mai manifesta' (cf. NODEX, s.v.). Ultimele

\footnotetext{
${ }^{18}$ Subst. făgăduită 'legămînt' apare și în $\mathrm{CC}_{2}$ (cf. INDICE XVI, p. 154).

${ }^{19}$ Din variatele semnificații pe care le are mgh. támadni, cea care se apropie cel mai mult de rom. tămădui este 'a se ridica' de unde în rom. 'a se ridica dintr-o boală, a se vindeca' (Mândrescu, 1892, p. 185). În aceeași ordine de idei, O. Densusianu (în ILR I, p. 242) observă că „ung. támadni 'a apărea, a se ridica’ = rom. tămăduire 'a fi în convalescență, a se recupera, a se vindeca’”.

${ }^{20}$ Față de creabantur în Vulgata, cf. ILR II, p. 307.

${ }^{21}$ Cf. și Studiu lingvistic la PH, p. 66.

${ }^{22}$ Redat în $\mathrm{CB}$ prin nevoiască-se.
} 
două ('a dispărea', 'a înceta') se află chiar în contradicție cu sensul etimologic care presupune, dimpotrivă, un 'moment inițial'. Legate de ideea 'a dispărea' pot fi discutate și sensurile înregistrate de dicționare: 'a fura' (cf. SD, s.v.) și 'a scăpa' (cf. CADE, s.v.), explicabile prin extensiune. Derivatele substantivale tămăduială, tămăduire păstrează nota semantică veche 'vindecare', iar subst. tămăduitor 'lecuitor' este notat în cărțile bisericești și cu sensul figurat 'Mîntuitor (Isus)'23. Acest din urmă sens este explicabil în contextul sărbătorii Paștilor, termenul mgh. (fel)-támad-(ás) avînd semnificația 'învierea', 'înălțarea' Domnului, continuînd, așadar, sensul primitiv 'ridicare' (din morți).

\section{Concluzii}

Împrumuturile maghiare lexicale reprezintă rezultatul firesc al conviețuirii celor două comunități lingvistice. Acestea au avut puterea de a determina structura vocabularului românesc chiar și dincolo de perioada contactului propriu-zis. Cu cît mai strînse și mai variate au fost raporturile interetnice, în special în anumite zone, cu atît mai intens s-au întrepătruns și cele două sisteme lingvistice și, implicit, de gîndire, fiecare reacționînd însă în chip diferit. Răspunsurile date de către limba-țintă la situația de „conflict” lingvistic și cultural ce se produce în urma contactelor pot fi urmărite, într-un mod cu totul aparte, în cazul schimbărilor semantice ale împrumuturilor. Acestea se prezintă edificatoare pentru studiul contactelor lingvistice, întrucît, așa cum s-a arătat, modificările petrecute în planul semnificatului pun în evidență nu numai mecanismele proprii ale funcționării limbii-țintă, dar și pe cele implicate în interacțiunea dintre limbi. Astfel, mai mult decît la nivelul fonetic sau morfo-sintactic, consecințele, probabil, cele mai profunde ale contactelor lingvistice pot fi surprinse în planul semnificației. Aceasta trebuie urmărită în evoluție, abordarea diacronică fiind cea mai eficientă, dacă nu cumva singura cale de a descrie consecințele contactelor interetnice și lingvistice conform cu realitatea lingvistică, întrucît simpla descriere a unui fenomen într-un anumit stadiu al limbii (române) nu rezolvă prea multe, înțelegerea profundă a acestuia venind din cunoașterea diacronică a apariției, dezvoltării și evoluției a tot ceea ce, apoi, a condus la existența fenomenului.

\section{Bibliografie}

\section{A. Surse}

$\mathrm{CC}_{1}=$ Coresi, Cazania I, cca 1567; ed. Vl. Drimba, București, Editura Academiei Române, 1998.

$\mathrm{CC}_{2}=$ Coresi, Cazania a II-a, Brașov, 1581; ed. S. Pușcariu și A. Procopovici, București, 1914.

CAT.C. = Coresi, Catehismul, text stabilit, studiu filologic, studio lingvistic și indice de A. Roman-Moraru, în TEXTE ROM., p. 19-128.

Св = Codicele Bratul, ediție de text de Al. Gafton, Editura Universității „Alexandru Ioan Cuza”, Iași, 2003.

$\mathrm{CP}=$ Texte de limbă din secolul XVI reproduse în facsimile îngrijite de I. Bianu, membru al Academiei Române. IV. Lucrul

Apostolesc. Apostolul tipărit de diaconul Coresi la Brașov în anul 1563, București, 1930.

Cs = Codex Sturdzanus, studiu filologic, studiu lingvistic, ediție de text și indice de cuvinte de Gh. Chivu, București, 1993.

$\mathrm{CV}=$ Codicele Voronețean, ediție critică, studiu filologic și studiu lingvistic de M. Costinescu, Editura Minerva, București, 1981.

Dî = Documente și însemnări românești din secolul al XVI-lea, text stabilit și indice de Gh. Chivu, M. Georgescu, M. Ioniță, Al.

Mareș și A. Roman-Moraru, cu o Introducere de Al. Mareș, București, 1979.

FRAG.TOD. = Fragmentul Todorescu, text stabilit, studiu filologic, studiu lingvistic și indice de I. Gheție, în TEXTE ROM., p. 259-364.

GB = Glosele Bogdan, text stabilit, studiu filologic, studiu lingvistic și indice de M. Georgescu, în TEXTE ROM., p. $365-463$.

PH = Psaltirea Hurmuzaki, I. Studiu filologic, studiu lingvistic și ediție de I. Gheție și M. Teodorescu, II. Indice de cuvinte de

Rovena Șenchi, București, 2005.

Po = Palia de la Orăştie (1582), I. Textul, Text stabilit și îngrijire editorială de V. Arvinte, I. Caproșu și Al. Gafton, Editura

Universității „Alexandru Ioan Cuza”, Iași, 2005.

PS = Psaltirea scheiană comparată cu celelalte Psaltiri din sec. XVIși XVII traduse din slavonește, edițiune critică de I.-A. Candrea,

București, 1916.

PS.C. = Psaltirea publicată românesce la 1577 de diaconulu Coresi, reprodusă cu unu studiu bibliograficu și unu glosaru com-

parativu de B. Petriceicu Hasdeu, edițiunea Academiei Române, tomulu I, textulu, Bucuresci, 1881.

\footnotetext{
${ }^{23}$ „Căci el este tămăduitorul sufletelor rănite” (Mândrescu, 1892, p. 185).
} 
TEXTE ROM. = Texte românești din secolul al XVI-lea. I. Catehismul lui Coresi. II. Pravila lui Coresi. III. Fragmentul Todorescu. IV. Glosele Bogdan. V. Prefețe și epiloguri, de Gheție, I. (coord.), Editura Academiei, București, 1982.

\section{B. Dicționare}

CADE = Candrea, I.-A. \& Adamescu, Gh., Dicționar enciclopedic ilustrat, Editura „Cartea Românească,” București, 1931.

Czuczor G. \& Fogarasi J. (1862-1874). A magyar nyelv szótára, I-VI, Pest.

DA = Dicționarul limbii române, București, 1913-1949.

DER = Ciorănescu, Al., Dicționarul etimologic al limbii române, ediție îngrijită și traducere din limba spaniolă, de T. Șandru

Mehedinți și M. Popescu Marin, Editura Saeculum I. O., București, 2002.

DEX = Dicționarul explicativ al limbii române.

DLRLV = Costinescu M., Georgescu M. \& Zgraon F., Dicționarul limbii române literare vechi (1640-1780). Termeni regionali,

București, Editura Științifică și Enciclopedică, 1987.

EWUR = Lajos, T., Etymologisch-historisches Wörterbuch der ungarischen Elemente im rumänischen, Budapest, 1966.

INDICE XVI = F. Dimitrescu et al., Indice lexical paralel. Secolul al XVI-lea, în Dimitrescu, F., Contribuţii la istoria limbii române vechi, Editura Didactică și Pedagogică, București, 1973, p. 122-245.

Lex. reg. = Lexic regional, coord. Gh. Bulgăr, vol. I, București, Editura Academiei, 1960, vol. II, [București], 1967.

$\mathrm{MESz}=$ Tótfalusi, I., Magyar etimológiai nagyszótár.

MNYSZ = Szarvas, G. \& Simonyi, Zs., Magyar nyelvtörténeti szótár, I-III, Budapest, 1890, 1891, 1893.

NODEX $=$ Noul dicționar explicative al limbii române.

SD = Scriban, A., Dicționaru limbii românești, Iași, 1939.

TRDW = Tiktin, H., Rumänisch-Deutsches Wörterbuch, Wiesbaden, (cu etimologii revăzute de Vasile Arvinte), 1985.

\section{Reviste de specialitate}

$\mathrm{CL}=$ „Cercetări de lingvistică, Cluj.

$\mathrm{DR}=$ „Dacoromania”, Buletinul Muzeului limbii române, Cluj.

MNY = „Magyar Nyelv”, ed. Szily Kálmán, Melich János, Magyar Nyelvtudományi Társaság, Budapest, 1920.

MNYR = „Magyar Nyelvőr”, ed. Simonyi Zsigmond, Magyar Tudományos Akadémia, Budapest 1898.

\section{Lucrări de referință}

Arvinte, V. \& Gafton, Al. (2007). Palia de la Orăștie (1582). II. Studii, Editura Universității „Alexandru Ioan Cuza,” Iași.

Bally, Ch. (1926). Le langage et la vie, Payot, Paris.

Bréal, M. (1897). Essai de sémantique (science des significations), Hachette, Paris.

Humboldt, W. v. (1836/2008). Über die Verschiedenheit des menschlichen Sprachbaues und ibren Einfluß auf die geistige Entwicklung des Menschengeschlechts, Berlin / Despre diversitatea structurală a limbilor și influența ei asupra dezvoltării spirituale a umanității, versiune românească, introducere, notă asupra traducerii, tabel cronologic, bibliografie și indici de E. Munteanu, București, Humanitas.

ILR I = Densusianu, O., Istoria limbii române, ediție îngrijită și traducere în limba română de J. Byck, vol. I, Originile, Editura Științifică, București, 1961.

ILR II = Densusianu, O., Istoria limbii române, ediție îngrijită și traducere în limba română de J. Byck, vol. II, Secolul al XVI-lea, Editura Științifică, București, 1961.

Gafton, Al. (2010). Consecințele profunde ale contactelor lingvistice, în „Studii de limbă română. Omagiu profesorului Grigore Brâncuș," Editura Universităţii din București, p. 77-100.

Gheție, I. \& Mareș, Al. (1974). Graiurile dacoromâne în secolul al XVI-lea, Editura Academiei, București.

Gombocz, Z. (1898). A jelenkori nyelvészet alapelvei, în MNYR, XXVII, p. 6-13, 53-61, 97-103, 193-201, 339-43, 433-8, 481-6.

Gombocz, Z. (1997). Jelentéstan és nyelvtörténet. Válogatott tanulmányok, Akadémiai Kiadó, Budapest.

Graur, Al. (1954). Incercare asupra fondului principal lexical al limbii române, Editura Academiei, București.

Király, F. (1990). Contacte lingvistice. Adaptarea fonetică a împrumuturilor românești de origine maghiară, Editura Facla, Timișoara.

Mândrescu, S.C. (1892). Elemente ungurești în limba română, București.

Meillet, A. (1905-1906). Comment les mots changent de sens, în „L'Année sociologique”, Felix Alcan, Paris, p. 1-38.

Meillet, A. (1948). Linguistique historique et linguistique générale, E. Champion, Paris.

Munteanu, E. (2008). Lexicologie biblică românească, Humanitas, București.

Niculescu, Al. (2005). Romania hungarica - contacte lingvistice și culturale româno-maghiare, în „L'altra latinita. Storia linguistica del romeno tra Oriente e Occidente”, Verona, Edizioni Fiorini, 2007; apărut și ca articol în „Studia Universitatis Petru Maior," Series Philologia, nr. 4, 2005, p. 112-137.

Pamfil, V. (1958). Elemente regionale în lexicul „Paliei de la Orăștie”, în CL, III, p. 227-248.

Paul, H. (1886). Prinzipien der Sprachgeschichte, ediția a doua, Max Niemeyer, Halle.

Pușcariu, S. (1940). Limba română, vol. I. Privire generală, București. 
Rosetti, Al. (1931). Limba română în secolul al XVI-lea, Editura „Cartea românească," București.

Simonyi, Zs. (1916). Jelentéstani szempontok, Magyar Tudományos Akadémia, Budapest, în „Értekezések a Nyelv- és Széptudományok köréből”, XXIII (1914-1921), nr. 3, p. 1-42.

Steinthal, H. (1855). Grammatik, Logik, und Psychologie, ihre Principien und ihr Verhältniss zu einander, Ferd. Dümmler, Berlin.

Steinthal, H. (1865). Zeitschrift für Völkerpsychologie und Sprachwissenschaft, Ferd. Dümmler, Berlin.

Vendryes, J. (1921). Le langage: introduction linguistique à l'histoire, Renaissance du livre, Paris.

Wundt, W. (1893). Logik, ediția a treia (1908), Verlag von Ferdinand Enke, Stuttgart.

Wundt, W. (1904). Völkerpsychologie. Eine Untersuchung der Entwicklungsgesetze von Sprache, Mythus und Sitte. Erster Band. Die Sprache, ediția a doua revizuită, Verlag von Wilhelm Engelmann, Leipzig.

Zolnai, B. (1920). Esztétikai szempontok a nyelvtudományban, în MNY, XVI (editat și în Nyelv és stílus, Gondolat, Budapest, 1957). 